Антонов А. В., д.держ.упр., професор (Житомирський державний технологічний університет, м. Житомир), Савіна Н. Б., д.е.н., професор (Національний університет водного господарства та природокористування, м. Рівне)

\title{
МЕХАНІЗМ ДЕРЖАВНОГО УПРАВЛІННЯ У СИСТЕМІ ЗБЕРЕЖЕННЯ ПРИРОДНОГО КАПІТАЛУ
}

У статті розглянуто фактичну структуру організаційноекономічного механізму збереження природного капіталу. Узагальнено підходи щодо механізму міжнародного державного відшкодування збереження лісових екосистем за Кіотським протоколом, основні переваги та недоліки такого механізму для України. Здійснено попереднє економічне обґрунтування запропонованого у роботі відшкодування.

Ключові слова: природний капітал, економіка, організація, механізм, природного капіталу.

Постановка проблеми. В останні два десятиріччя людство все більше відчуває зміни клімату. Особливо непокоїть стан атмосферного повітря, його надзвичайна забрудненість шкідливими речовинами, насамперед вуглекислим газом, метаном, оксидами азоту та ін. Поліпшення ситуації можливе лише за умови запровадження природоохоронних проектів, енергоефективного виробництва та екологічно чистого обладнання. Проте такі проекти на сьогодні $\epsilon$ надто дорогими для України, яка тільки починає ставати на шлях сталого розвитку. Реальними шляхами стабілізації ситуації залишається збереження природного капіталу, реалізації механізмів Кіотського протоколу, залучення інноваційних інструментів у функціонування організаційно-економіного механізму природоохоронної діяльності.

Аналіз останніх досліджень та публікацій. Природний капітал формує безпечне для життя і здоров'я людини навколишнє середовище, забезпечує населення продуктами харчування, ліками, сировиною для промисловості. Крім того, підтримує функціонування екосистем, зокрема кругообіг і очищення природних вод, збереження ґрунтів і стабільність клімату. Саме тому питанню збереження природного капіталу присвячено цілу низку праць вітчизняних науковців [1-9], зокрема А. Ю. Александрової, О. О. Веклич, О. В. Врублевської, Л. С. Гринів, Ю.М. Грищенка, П.І. Гамана, Л. Г. Мельника, І. М. Синякевича та ін., які в основному стосуються підтримання екологічного стану екосистем. Проте, як свідчать праці іноземних фахів- 
ців (С. Н. Бобильова, Г. А. Моткина, А. С. Тулупова, А. N. James, M. J. B. Green, J. Paine, J. Dixon, S. Pagiola, B. I. E. Brink, R. W. Butler ta ін.), для ефективного збереження і обліку природний капітал має відображатися у національних рахунках кожної держави та мати стабільну фінансову основу, що можливо втілити у ефективному організаційно-економічному механізмі. Все це зумовило актуальність даної теми наукової роботи, ії мету, а також визначило предмет та об'єкт дослідження.

Метою дослідження $€$ розроблення заходів щодо формування організаційно-економічного механізму функціонування природного капіталу на основі кращого вітчизняного та зарубіжного досвіду. Об'єктом дослідження $€$ сучасний стан функціонування основних компонентів природного капіталу України. Предметом дослідження виступає процес побудови дієвого і ефективного організаційноекономічного механізму збереження природного капіталу. Принагідно постає запитання, що собою являє природний капітал, і як розуміють це поняття у класичному значенні.

Виклад основного матеріалу. Відомо, що природний капітал це запаси, що складаються з життєпідтримуючих систем (систем життєзабезпечення), біорізноманіття, відновлюваних і невідновних ресурсів, використовуваних людиною або таких, що представляють для неї інтерес. Природний капітал, або природне багатство - включає запаси природних активів, таких як грунт і ліси, тваринний світ і водні ресурси, біологічні види, ландшафт, зволожені землі. Іноді кажуть про включення в це поняття асиміляційної ємності екосистем, урахування ефекту біогеохімічних циклів і енергетичних потоків. Природний капітал розглядається як актив в економіці з потенціалом збільшення продуктивності і благополуччя людей. Наприклад, цінність природного ресурсу як економічного активу залежить від величини доходу або благополуччя, який він може принести. Продуктивність антропогенного (створеного людиною) капіталу дедалі більше обмежується скороченням розмірів природного капіталу.

У традиційній економічній науці аналогом природного капіталу $€$ фактор виробництва «земля», що розуміється як природна складова економіки, жорстко обмежена в розмірах економічної пропозиції. Прихильники концепції природного капіталу (у тому числі представники «зеленої економіки») вважають термін «природний капітал» точнішим, оскільки, наприклад, якість земельних угідь можна покращити або погіршити подібно якості штучного (виробленого людьми) капіталу. Інша аналогія: автомобільний завод виробляє автомобілі, як яблуня продукує яблука [2-4].

Концепція природного капіталу істотно вплинула на сучасну 
практику розрахунку макроекономічних показників. Світовий банк нині враховує при їхньому аналізі обсяги видобутку природних ресурсів та екологічної шкоди, викликаної викидами вуглекислого газу (парниковий ефект).

Як показало дослідження, у сучасній практиці стримування побудови дієвого організаційно-економічного механізму збереження природного капіталу зумовлено такими причинами [6; 8]:

1. Відсутністю потреби у визначенні реальної ринкової вартості природних та суспільних ресурсів, і, як наслідок, застосування великої кількості суб'єктивних оцінок, розрахованих на економічно необґрунтованій основі;

2. Відсутністю у нашій державі правового поля проведення економічної оцінки ресурсів природного капіталу;

3. Відомчим підходом до організації збереження ресурсів природного капіталу, оскільки розроблення методології певного виду ресурсу здійснювали організації, підпорядковані відомствам, які займалися використанням та відтворенням даного виду ресурсу.

Україна сьогодні, у зв'язку із загрозою глобальної екологічної кризи, не може залишатися осторонь від сформованого у світі ринку екосистемних послуг, оскільки зволікаючи із його формуванням національна економіка щорічно втрачає іноземні інвестиції на розвиток природоохоронної діяльності. Пропонуються такі напрями розвитку ринку екосистемних послуг [8]:

1. Ринок генетичних ресурсів країн-учасниць Конвенції «Про біологічне різноманіття» (стаття 15). Доступ до генетичних ресурсів і справедливий розподіл вигод за користування ними (штами мікроорганізмів, у тому числі промислових, лікарська сировина рослинного і тваринного походження, селекційні ресурси, матеріали кріобанків);

2. Ринок квот на викиди вуглекислого газу і зв'язування вуглецю шляхом сприяння лісовідновленню (Кіотський протокол, 1997). За оцінками Україна здатна отримувати 7,5 млрд дол. США щорічно;

3. Ринок «боргів за природу» (Польща, Болівія, Коста-Ріка, Мадагаскар). Можливість реструктуризації зовнішнього боргу України (104 млрд дол. США або 88,9\% ВВП). Інвестиції у розвиток екотуризму на ПЗТ, перепрофілювання підприємств, що наносять збиток унікальним природним об'єктам (Світовий Банк, Інститут Світових ресурсів, ООН);

4. Ринок екосистемних послуг, пов'язаний із внеском природних екосистем у глобальну стійкість біосфери (ГЕФ). Ідея міжнародних взаєморозрахунків за збереження глобальної стійкості, розвинуті країни у Ріо-де-Жанейро підписали зобов'язання спрямовувати на ці 
цілі 0,7\% свого ВВП. Для України такі компенсації можуть становити від 2-6\% ВВП.

Узагальнення вітчизняного і міжнародного досвіду, викладеного у працях фахівців [1-9] дозволив виділити шість підходів до економічної оцінки функціонування природного капіталу (економічна оцінка за кінцевими народногосподарськими результатами, соціально-економічна оцінка, експертна оцінка, затратні методи, рентний підхід і концепція загальної економічної цінності). Найбільш перспективною $€$ концепція загальної економічної цінності, оскільки забезпечує комплексний підхід до оцінки природного капіталу [8; 9].

Дослідження теоретичних основ та прикладних проблем збереження природного капіталу в Україні, проведене на прикладі лісових екосистем, зумовлює постановку таких цілей:

- обґрунтувати ефективність застосування механізмів Кіотського протоколу в Україні;

- запропонувати механізм відшкодування втрат за збереження лісових ресурсів на міжнародному рівні;

- окреслити перспективи збереження природного капіталу на основі запровадження інноваційних проектів.

Виклад основного матеріалу. У грудні 1997 р. у місті Кіото (Японія) країни світової спільноти підписали історичну угоду про контроль над атмосферними викидами парникових газів, що спричиняють глобальне потепління. Україна 4 лютого 2004 р. ратифікувала Кіотський протокол. Цей документ передбачає, що країна, маючи менший обсяг викидів, може продавати вивільнені квоти країнам з надлишком викидів. Оскільки вуглець консервується на достатньо тривалий час у вигляді біогенної речовини переважно у лісах, тому дане дослідження ґрунтується саме на розрахунках продукування кисню лісами та здатністю їх поглинати вуглекислий газ [3; 11; 12].

Чергова конференція ООН з проблеми зміни клімату в столиці Катару Досі дала «друге життя» Кіотському протоколу. Одним із важливих рішень була пропозиція створити у 2013 р. інститут компенсації збитків і втрат, викликаних небезпечними наслідками зміни клімату в країнах, що розвиваються. Таким чином, дана конференція стала ключовою точкою на шляху до більш масштабної боротьби зі зміною клімату. Країни-учасниці Кіотського протоколу більшістю голосів ухвалили поправку до угоди по другому періоду його роботи, який розпочався в 2013 році і завершиться в 2020 році. Про свою відмову брати участь у Кіото-2 заявили Росія, Японія та Нова Зеландія, а також Канада, яка в грудні 2011 року офіційно вийшла з угоди. Таким чином, зобов'язання в межах Кіото-2 взяли ЄС, Австралія, Казахстан, Україна, Білорусь, Норвегія, Швейцарія, Ісландія, Ліхтенштейн і 
Монако [12].

Механізми Кіотського протоколу передбачають можливість торгувати квотами на викиди парникових газів, а також можливість спільного впровадження проектів зі скорочення таких викидів. За оцінками науковців, продаж квот на викиди парникових газів може бути прибутковою справою для України, за рахунок торгівлі квотами Україна зможе отримувати щороку 2,5 млрд євро.

Україна 14 липня 2008 р. підписала з Японією меморандум, що дозволив почати торгівлю квотами на викид парникових газів. Отримані кошти використовували на модернізацію українських підприємств. У підписанні документа брали участь колишній міністр навколишнього природного середовища Георгій Філіпчук і посол Японії в Україні Муцуо Мабучі. За словами міністра, Україна готова щорічно знижувати викиди $\mathrm{CO}_{2}$ на 18 млн тонн. Загальний обсяг скорочень викидів упродовж 2008-2012 рр. становить 208 млн тонн $\mathrm{CO}_{2}$. Квота України на викид парникових газів, за Кіотським протоколом, становить 923 млн тонн щорічно. Фактичний обсяг не перевищує 440-460 млн тонн. Решту 460-480 млн тонн щорічно, починаючи 3 2008 р., продавали. За умови збереження нинішніх темпів виробництва в Україні до 2012 р. йшлося про квоту в розмірі до 2 млрд тонн. У Мінприроди відзначили, що Україна щорічно зможе продавати до 500 млн тонн парникових газів за ціною близько 15 доларів США за тонну.

Україна і Японія у 2013 році погодили 536 проектів в 24 регіонах країни, які реалізовувалися за кошти, отримані від продажу цій країні одиниць скорочення викидів у рамках зобов'язань за Кіотським протоколом. Загальна вартість цих проектів оцінюється в 3,814 млрд грн. До США, Індії і Китаю, які не ратифікували протокол, приєдналися Канада, Японія, Нова Зеландія і Росія, що заявили про вихід з угоди. У грудні 2011 року у місті Дурбан Південноафриканської республіки учасники форуму зі 194 країн домовилися продовжити чинність Кіотського протоколу до 2020 року. У грудні 2012 року Кіотський протокол продовжили 200 країн до 2020 року.

Потенційними покупцями українських квот $є$ держави, які перевищують власний ліміт. Крім Японії, найбільшим попитом квоти користуватимуться в держав Євросоюзу, Канади - країн, які мають їх дефіцит. На сьогоднішній день Україна сподівається на одержання доходів від продажу квот на викиди. Крім того, значним потенційним ресурсом виконання умов протоколу $є$ механізм «проектів спільного здійснення», коли за рахунок іноземних інвестицій відбувається зниження емісії, яке зараховується країні-інвестору. Разом з тим си- 
туація з виконанням вимог Кіотського протоколу для України, особливо в недалекому майбутньому, не $є$ такою обнадійливою, що пов'язано із низькою ефективністю виробництва i, як наслідок, значним перевищенням рівня викидів, що припадають на одиницю ВВП. Так, викиди $\mathrm{CO}_{2}$ на одиницю ВВП в Україні вищі ніж у країнах ЄС приблизно у 4 рази, ніж у США - у 2,5 рази $[3 ; 4 ; 6 ; 12]$.

Оскільки за Кіотським протоколом країни можуть економічно компенсувати свої позитивні впливи на навколишнє середовище за рахунок держав-забруднювачів, то спочатку необхідно виміряти та оцінити такі впливи. Тому у даній роботі основна увага сконцентрована на порівнянні площ і здатностей лісових екосистем України та інших країн світу депонувати вуглець та розрахувати той економічний зиск, який вони можуть здобути завдяки Кіотському протоколу. У основу такого дослідження покладено економічний розрахунок депонування вуглецю лісами тих країн, які межують з Україною та можуть стати ії стратегічними партнерами при реалізації Кіотського протоколу [3; 5; 7].

На сьогодні загальна площа лісів України становить 10,5 млн га [9], з них хвойні ліси (сосна, ялина) займають 42,2\%, твердолистяні (дуб, бук) - 43,2\%, м'яколистяні - 13,6\% (табл. 1). Як засвідчують матеріали наукових публікацій ліси України зріджені, низькоповнотні. Недостатній догляд у молодих лісах та надмірні вирубування у пристигаючих і стиглих лісостанах призводять до зниження не лише продуктивності, а й біологічної стійкості лісів.

Площа боліт України досягає 975,8 тис. га, що складає 1,6\% [9] всієї території держави (табл. 1). Найбільше боліт на Поліссі. У лісостеповій і степовій зонах болота здебільшого розміщені в заплавах річок. За рівнем заболоченості й характером боліт в Україні виділяють п'ять торфо-болотних областей: Полісся, Мале Полісся, Лісостеп, Степ, Карпати. Значна частина боліт осушена й використовується у сільському та лісовому господарстві.

Отже, лісові та болотні екосистеми займають вагому частку у структурі земельних угідь України та формують основу усього природного капіталу держави.

Сьогодні відомо, що ліси та болота мають вагоме значення у підтриманні екологічного балансу території, продукують життєво важливий елемент для суспільства - кисень. Ліси виступають у якості об'єкта туристично-рекреаційної діяльності, мисливства. Болота мають здатність до природного очищення води. Вони значною мірою задовольняють соціальні потреби у любительській та промисловій рибній ловлі. Велике рекреаційне значення мають водні об'єкти, придатні для купання, бальнеологічні ресурси у вигляді мінеральних 
вод, мінеральних грязей. Місцеве населення, яке традиційно займається рибальством, полюванням, сільським господарством створює свій особливий спосіб життя, який є частиною національної культурної спадщини $[1 ; 2 ; 3 ; 8]$. Тому упевнено можна стверджувати, що заболочені території мають вагоме соціально-економічне значення у розвитку регіону.

Таким чином, лісові та болотні екосистеми займають вагому частку у структурі земельних угідь України та формують основу усього природного капіталу держави.

Сьогодні відомо, що ліси та болота мають вагоме значення у підтриманні екологічного балансу території, продукують життєво важливий елемент для суспільства - кисень. Ліси виступають у якості об'єкта туристично-рекреаційної діяльності, мисливства. Болота мають здатність до природного очищення води. Вони значною мірою задовольняють соціальні потреби у любительській та промисловій рибній ловлі. Велике рекреаційне значення мають водні об'єкти, придатні для купання, бальнеологічні ресурси у вигляді мінеральних вод, мінеральних грязей. Місцеве населення, яке традиційно займається рибальством, полюванням, сільським господарством створює свій особливий спосіб життя, який є частиною національної культурної спадщини $[1 ; 2 ; 3 ; 8]$. Тому упевнено можна стверджувати, що заболочені території мають вагоме соціально-економічне значення у розвитку регіону.

Одним із структурних елементів організаційно-економічного механізму збереження природного капіталу України урахування економічного оцінювання екологічних функцій лісових і болотних екосистем, що включає депонування вуглецю, очищення атмосфери лісом та води болотами [3].

Знаючи, що один гектар лісу виділяє в середньому щороку 5 тонн кисню, а поглинає 20 тонн вуглекислого газу, а також норму споживання кисню на душу населення, у даному дослідженні встановлено річну масу депонування вуглецю лісами, які розміщені на території країн-сусідів та встановлено загальну чисельність населення, життєдіяльність яких буде забезпечена киснем. З'ясувалося, що Польща, Україна, Румунія, Чехія, Словаччина, Угорщина, Росія є донорами кисню для інших країн. За положеннями Кіотського протоколу вони мають право на отримання компенсації завдяки функціонуванню лісових екосистем та забезпечення життєдіяльності населення. Причому, встановлено надлишок чисельності населення цих держав, яка може бути забезпечена киснем у інших країнах, де лісові екосистеми у дефіциті. 
Висновки. Отже, організаційно-економічний механізм збереження природного капіталу має складну багатогранну структуру: включає як вже давно існуючі інструменти (штрафи, податки, пеня), так й має охоплювати інноваційні інструменти: реалізацію Кіотського протоколу, гранти, субсидії, екологічне кредитування, субвенції, екологічне страхування та ін. Насамперед реальною можливістю для України отримати фінансові кошти для удосконалення своєї внутрішньої природоохоронної політики є Кіотський протокол. Україна повинна бути зацікавлена в тому, щоб механізми Кіотського протоколу продовжували діяти і на перспективу до 2020 року. Даний механізм дає нашій промисловості та енергетиці реальний шанс одержати гроші на реалізацію проектів у сфері підвищення енергоефективності. Україна одержала грант Світового банку на 5 мільйонів доларів для впровадження національної схеми торгівлі надлишками викидів $\mathrm{CO}_{2}$ з перспективою приєднатися до Європейського ринку квот. Але для цього нашій країні необхідно зробити все можливе, щоб другий період дії Кіотського протоколу справді запрацював.

1. Александрова А. Ю. Экономика и организация заповедников и национальных парков. М. : Турист, 1991. 112 с. 2. Аболин Р. И. Опыт эпигенологической классификации болот. Болотоведение. 1914. Вып. 3. С. 1-55. 3. Моткин Г. А. Страхование риска нарушения устойчивости средообразующих функций экосистем. Материалы III международной научнопрактической конференции «Эколого-экономический механизм сохранения биоразнообразия особо охраняемых природных территорий» (Беловежская пуща). Каменюки, 2008. С. 26-28. 4. James A. N., Green M. J. B. and Paine J. Financial indicators and targets for protected areas. Background paper for GBF6: Dialogue on Biodiversity Indicators and Targets. Unpublished draft for discussion only. 1997. P. 55. 5. Dixon J., Pagiola S. Local Costs, Global Benefits: Valuing Biodiversity in Developing Countries. Environmental Department. The World Bank, 2000. P. 13. 6. Brink B. I. E. 2000. Biodiversity Indicators for the OECD Environmental Outlook and Strategy: a feasibility study. RIVN report, Bilthoven, The Netherlands. 52 p. 7. Butler R. W. 1991. Tourism, Environment, and Sustainable Development. Environmental Conservation, 18/3. P. 201-208. 8. Статистичний щорічник України за 2014 р. / за ред. О. Г. Осауленка. Київ : Видавництво «Консультант», 2015 р. С. 522. 9. Сторони Кіотського протоколу затвердили другий період угоди. URL: http://www.ecolive.com.ua/content/blogs/storoni-kiotskogo-protokolu-zatverdili-drugiyperiod-ugodi (дата звернення: 10.10.2018). 10. Проскуряков О. Нову угоду на заміну Кіотського протоколу підпишуть у 2015 році. URL: http://uaenergy.org/post/32004 (дата звернення: 10.10.2018). 11. Кіотський протокол діятиме до 2020 p. URL: http://ipress.ua/news/ kiotskyy_protokol_diyatyme_do_2020_roku_12611.html (дата звернення: 10.10.2018).

\section{REFERENCES:}


1. Aleksandrova A. Yu. Ekonomika y orhanizatsyia zapovednikov i natsyonalnykh parkov. M. : Turist, 1991. 112 s. 2. Abolin R. Y. Opyt epihenolohycheskoi klassifikatsyi bolot. Bolotovedeniie. 1914. Vyp. 3. S. 1-55. 3. Motkin H. A. Strakhovanie riska narusheniia ustoichyvosty sredoobrazuiushchykh funktsyi ekosystem. Materialy III mezhdunarodnoi nauchnopraktycheskoi konferentsyi "Ekoloho-ekonomicheskyi mekhanizm sokhraneniia bioraznoobraziia osobo okhraniaiemykh prirodnykh territoryi" (Belovezhskaia pushcha). Kameniuky, 2008. S. 26-28. 4. James A. N., Green M. J. B. and Paine J. Financial indicators and targets for protected areas. Background paper for GBF6: Dialogue on Biodiversity Indicators and Targets. Unpublished draft for discussion only. 1997. R. 55. 5. Dixon J., Pagiola S. Local Costs, Global Benefits: Valuing Biodiversity in Developing Countries. Environmental Department. The World Bank, 2000. R. 13. 6. Brink B. I. E. 2000. Biodiversity Indicators for the OECD Environmental Outlook and Strategy: a feasibility study. RIVN report, Bilthoven, The Netherlands. 52 p. 7. Butler R. W. 1991. Tourism, Environment, and Sustainable Development. Environmental Conservation, 18/3. R. 201-208. 8. Statystychnyi shchorichnyk Ukrainy za 2014 r. / za red. 0. H. Osaulenka. Kyiv : Vydavnytstvo «Konsultant», 2015 r. S. 522. 9. Storony Kiotskoho protokolu zatverdyly druhyi period uhody. URL: http://www.eco-live.com.ua/content/blogs/storoni-kiotskogo-protokoluzatverdili-drugiy-period-ugodi (data zvernennia: 10.10.2018). 10. Proskuriakov 0 . Novu uhodu na zaminu Kiotskoho protokolu pidpyshut u 2015 rotsi. URL: http://ua-energy.org/post/32004 (data zvernennia: 10.10.2018). 11. Kiotskyi protokol diiatyme do 2020 r. URL: http://ipress.ua/news/ kiotskyy_protokol_diyatyme_do_2020_roku_12611.html (data zvernennia: 10.10.2018).

Рецензент: д.е.н., професор Якимчук А. Ю. (НУВГП)

Antonov A. V., Doctor of Public Administration, Professor (Zhytomyr State Technical university, Zhytomyr), Savina N. B., Doctor of Economics, Professor (National University of Water and Environmental Engineering, Rivne)

\section{MESCHANISM OF PUBLIC ADMINISTRATION IN THE SYSTEM OF NATURE CAPITAL CONSERVATION}

The approaches of the government compensation mechanism maintaining forest ecosystems in accordance with the Kyoto Protocol, the main advantages and disadvantages of such mechanism for Ukraine have been done. The preliminary feasibility study proposed in the refund has been ordered. 
Keywords: natural capital, meschanism, biodiversity, economics.

Антонов А. В., д.гос.упр., профессор (Житомирский государственный технологический университет, г. Житомир), Савина Н. Б., д.э.н., профессор (Национальный университет водного хозяйства и природопользования, г. Ровно)

\section{МЕХАНИЗМ ГОСУДАРСТВЕННОГО УПРАВЛЕНИЯ В СИСТЕМЕ СОХРАНЕНИЯ ПРИРОДНОГО КАПИТАЛА}

В статье рассмотрены основные составляющие организационноэкономического механизма сохранения биоразнообразия. Обобщены подходы относительно механизма международного государственного возмещения сохранения лесных экосистем по Киотскому протоколу, основные преимущества и недостатки такого механизма для Украины. Осуществлено предварительное экономическое обоснование предложенного в статье возмещения.

Ключевые слова: природный капитал, механизм, биоразнообразие, экономика. 